\title{
GAMBARAN PERESEPAN PASIEN SIROSIS HATI DI INSTALASI RAWAT JALAN RUMAH SAKIT PANTI WALUYO SURAKARTA
}

\section{DESCRIPTION OF HEART SIROSIS PATIENT PREPARATION IN INSTALLATION OF PANTI WALUYO HOSPITAL SURAKARTA}

\author{
Endah Sulistyoningrum ${ }^{1 *}$, Lusia Murtisiwi² \\ Email: end4hsulist@gmail.com \\ 1,2 Program Study D3 Farmasi,Stikes Nasional, Surakarta, Indonesia
}

\begin{abstract}
Abstrak
Sirosis hati merupakan keadaan patologis yang menggambarkan stadium akhir fibrosis hepatik yang berlangsung progresif ditandai dengan distorsi dari arsitektur hepar dan pembentukan nodulus regeneratif. Berdasarkan profil kesehatan DIY tahun 2008, sirosis hati masuk dalam sepuluh besar penyebab kematian tertinggi di Provinsi DIY dengan prevalensi $1,87 \%$ pada urutan kesembilan. Tujuan dilakukan penelitian ini adalah untuk mengetahui gambaran peresepan pasien sirosis hati di Instalasi Rawat Jalan Rumah Sakit Panti Waluyo. Penelitian ini merupakan penelitian deskriptif yang dilakukan secara retrospektif. Sampel dalam penelitian ini adalah sampel jenuh, yaitu semua anggota dari populasi data rekam medik pasien yang didiagnosis sirosis hati di Instalasi Rawat Jalan Rumah Sakit Panti Waluyo, dijadikan sebagai sampel dengan tetap memperhatikan kriteria inklusi dan eksklusi yaitu pasien sirosis hati dari poliklinik internis dengan atau tanpa komplikasi, memiliki data jelas, lengkap dan pada data rekam mediknya minimal memuat data nama, umur, jenis kelamin, diagnosa, terapi dan tanpa komplikasi HIV dan onkologi, yaitu sebanyak 61 lembar rekam medik. Berdasarkan hasil penelitian selama tahun 2019 didapatkan pasien laki-laki sebanyak $55,74 \%$ dan perempuan $44,26 \%$. Penyakit penyerta komplikasi pada pasien sirosis hati adalah asites sebanyak $39,34 \%$, hipertensi porta sebanyak $19,67 \%$, varises esofagus $11,48 \%$, ensefalopati hati $3,28 \%$. Pasien mendapat terapi obat tunggal yaitu propranolol dan spironolactone masing-masing sebanyak $1,64 \%$, dan mendapat terapi kombinasi kombinasi 2 obat paling banyak yaitu propranolol+curcuma sebanyak $19,67 \%$, dan mendapat kombinasi lebih dari 2 obat paling banyak yaitu propranolol+spironolactone+curcuma sebanyak $11,47 \%$.
\end{abstract}

Kata kunci :Sirosis Hati, gambaran peresepan, RS Panti Waluyo

ABSTRACT

Liver cirrhosis is a pathological condition that describes the end-stage progressive hepatic fibrosis characterized by distortion of the liver architecture and the formation of regenerative nodules. Based on the DIY healthprofile in 2008, liver cirrhosis was among the top ten causes of death in DIY Province with a prevalence of $1,87 \%$ in the ninth place. The purpose of this study was to determine the picture of prescribing liver cirrhosis patients in the Outpatient Installation of Panti Waluyo Hospital. This research is a descriptive study conducted retrospectively. The sample in this study was a saturated sample, that is all members of the population medical record data of patients diagnosed with liver cirrhosis in the Outpatient Installation of Panti Waluyo Hospital, used as a sample with due regard to the inclusion and exclusion criteria, namely liver cirrhosis patients from internal polyclinics with or without complications, have clear,complete data and the medical record data at least contains data on name, age, gender, diagnosis, therapy and without complications of HIV and Oncology, as many as 61 sheets of medical records. Based on the results of research 
during 2019 it was found that male patients were 55,74\% and women 44,26\%. Complicating comorbidities in liver cirrhosis patients were ascites 39,34\%, portal hypertension 19,67\%, esophageal varices $11,48 \%$, liver encephalopathy 3,28\%. Patients received single drug therapy namely propranolol and spironolactone as much as $1,64 \%$, and received the most combinations of 2 drug combinations, namely propranolol-curcuma as much as 19,67\%, and received a combination of more than 2 drugs at most, namely propranolol-spironolactone-curcuma as much as $11,47 \%$ Keywords: Cirrhosis of the liver, prescribing picture, Panti Waluyo Hospital

\section{PENDAHULUAN}

Sirosis hati merupakan keadaan patologis yang menggambarkan stadium akhir fibrosis hepatik yang berlangsung progresif ditandai dengan distorsi dari arsitektur hepar dan pembentukan nodulus regeneratif.. Sirosis dapat dijumpai di seluruh negara termasuk Indonesia dengan kejadian yang berbeda-beda di tiap negara. Berdasarkan data dari WHO tahun 2004 sirosis menempati urutan kedelapan belas penyebab kematian dengan jumlah kematian 800.000 kasus dengan prevalensi 1,3\% (Nurdjanah, 2007; Patasik dkk., 2015).

Angka kematian akibat sirosis hati masih tergolong tinggi di Indonesia. Sirosis hati banyak dihubungkan dengan infeksi virus hepatitis B dan C. Menurut laporan sebuah rumah sakit umum pemerintah di Indonesia, rata-rata prevalensi sirosis hati adalah 3,5\% dari seluruh pasien yang dirawat di Bangsal Penyakit Dalam. Di Indonesia sirosis hati dengan komplikasinya merupakan suatu masalah kesehatan yang masih sulit diatasi. Kebanyakan pasien sirosis meninggal pada dekade keempat atau kelima kehidupan. (Farida dkk., 2014).

Komplikasi yang terjadi pada sirosis hati akan meningkatkan risiko kematian dan angka kesakitan pasien, komplikasi yang dapat terjadi adalah perdarahan saluran cerna, asites, sindrom hepatorenal, enselofati hepatik, peritonitis bakterial spontan dan karsinoma hepatoselular (Lovena dkk., 2017).

Berdasarkan latar belakang yang telah diuraikan, perlu dilakukan penelitian dengan tujuan untuk mengetahui gambaran peresepan pada pasien sirosis hati di Instalasi Rawat Jalan Rumah Sakit Panti Waluyo Surakarta.

Hasil akhir dari penelitian ini diharapkan dapat memberikan masukan terkait ketersediaan obat, penggunaan obat yang diharapkan dapat memberikan kontribusi pada pembuatan formularium rumah sakit, dan tentang gambaran peresepan pada pasien sirosis hati.

\section{METODE PENELITIAN}

Penelitian ini merupakan penelitian non eksperimental, yaitu penelitian yang berdasarkan pada data-data yang sudah ada tanpa melakukan perlakuan terhadap subyek uji dengan rancangan analisis secara deskriptif (Notoatmodjo, 2012).

Pengumpulan data dilakukan secara retrospektif (data yang sudah ada), yaitu pengumpulan data dengan cara melakukan penelusuran catatan rekam medik yang diberikan pada pasien di Instalasi Rawat Jalan Rumah Sakit Panti Waluyo Surakarta. Populasi penelitian ini adalah data rekam medik pasien rawat jalan sirosis hati yang tercatat pada lembar rekam medik di Instalasi Rawat Jalan Rumah Sakit Panti Waluyo pada tahun 2019.

\section{HASIL DAN PEMBAHASAN}

Karakteristik pasien sirosis hati berdasarkan jenis kelamin, usia pasien, diagnosis di Instalasi Rawat Jalan Rumah Sakit Panti Waluyo pada tahun 2019 adalah

Tabel I. Karakteristik pasien sirosis hati berdasarkan jenis kelamin

\begin{tabular}{ccc}
\hline Jenis kelamin & Frekuensi & Persentase(\%) \\
\hline Laki-laki & 34 & 55,74 \\
Perempuan & 27 & 44,26 \\
\hline Total & 61 & 100,00 \\
\hline
\end{tabular}


Pada tabel 1 dapat dilihat karakteristik pasien sirosis hati di Instalasi Rawat Jalan Rumah Sakit Panti Waluyo pada tahun 2019.

Berdasarkan jenis kelamin dapat diketahui bahwa jenis kelamin laki-laki lebih banyak daripada perempuan dengan persentase $55,74 \%$ untuk pasien laki-laki dan 44,26\% untuk pasien perempuan. Hal ini dikarenakan laki-laki lebih berisiko mengidap sirosis hati kemungkinan karena laki-laki sebagai kepala rumah tangga yang harus bekerja lebih keras tanpa memperhatikan kemampuan fisik dan mentalnya sehingga lebih mudah terkena penyakit. Selain itu juga dapat dikaitkan dengan kebiasaan laki-laki yang sering mengonsumsi alkohol dimana alkohol merupakan salah satu penyebab terjadinya sirosis hati (Stiphany, dkk, 2011).

Tabel II. Karakteristik pasien sirosis hati berdasarkan usia

\begin{tabular}{cccc}
\hline Usia Pasien & Klasifikasi & Frekuensi & Persentase(\%) \\
\hline 0-17 tahun & Anak-anak dibawah umur & 1 & 1,64 \\
18-65 tahun & Pemuda & 55 & 90,16 \\
\multirow{2}{*}{ 66-79 tahun } & Setengah baya & 5 & 8,20 \\
\hline & & 61 & $100,00 \%$ \\
\hline
\end{tabular}

Berdasarkan tabel 2 menunjukkan usia pasien sirosis hati di Instalasi Rawat Jalan Rumah Sakit Panti Waluyo pada tahun 2019 paling banyak terjadi pada usia 18-65 tahun yaitu 55 pasien dengan persentase 90,16\%. Berdasarkan hasil penelitian yang dilakukan Virgonita dan Zulkarnain (2012) menyimpulkan bahwa risiko sirosis hati lebih sering terjadi pada usia 34-64 tahun $(85,51 \%)$ dibandingkan usia $\geq 65$ tahun(14,49 \%). Menurut Tarigan (2004) usia rata-rata pasien adalah 46-55 tahun, sesuai dengan data dari suatu sumber yang menyebutkan bahwa kejadian sirosis terbanyak pada dekade kelima.
Hal ini terjadi karena sirosis hati merupakan penyakit hati kronik yang akan muncul seiring bertambahnya usia. Gejala dan tanda penyakit ini baru akan muncul bertahuntahun kemudian setelah penderita terpapar faktor risiko dalam waktu yang lama ataupun pernah mengalami penyakit hati lain seperti hepatitis.

Penderita yang sudah terkena sirosis hati berat jika tanpa perawatan sekitar 15\% pasien sirosis hati akan meninggal dalam lima tahun (Stiphany, dkk, 2011).

Tabel III. Karakteristik pasien sirosis hati berdasarkan diagnosis

\begin{tabular}{|c|c|c|}
\hline \multirow{2}{*}{$\begin{array}{r}\text { Diagnosis } \\
\text { Dengan penvakit penverta }\end{array}$} & Frekuensi & \multirow[t]{2}{*}{ Persentase } \\
\hline & & \\
\hline 1. Asites & 24 & $39,34 \%$ \\
\hline 2. Hipertensi Porta & 12 & $19,67 \%$ \\
\hline 3. Varises Esofagus & 7 & $11,48 \%$ \\
\hline 4. Enselofati Hati & 2 & $3,28 \%$ \\
\hline Asites + Hipertensi Porta & 8 & $13,11 \%$ \\
\hline Asites + Varises Esofagus & 4 & $6,56 \%$ \\
\hline Asites + Diabetes Melitus & 2 & $3,28 \%$ \\
\hline $\begin{array}{l}\text { 8. Asites }+ \text { Hipertensi Porta }+ \text { Diabetes } \\
\text { Melitus }\end{array}$ & 2 & $3,28 \%$ \\
\hline Total & 61 & $100 \%$ \\
\hline
\end{tabular}


Berdasarkan rekap dari 61 pasien sirosis hati di Instalasi Rawat Jalan Rumah Sakit Panti Waluyo, semua pasien didiagnosa dengan penyakit penyerta dengan persentase $100 \%$.

Berdasarkan hasil yang diperoleh, asites adalah penyakit penyerta yang paling banyak ditemukan pada pasien penderita sirosis hati dengan jumlah 24 pasien dengan persentase 39,34\%, kemudian disusul dengan komplikasi sirosis hati dengan hipertensi porta sebanyak 12 pasien dengan persentase 19,67\%.

Penelitian yang dilakukan oleh Stiphany,dkk pada pasien rawat inap di RSUD DR R.D. Pirngadi Medan pada tahun 2011, penyakit yang banyak menyertai sirosis hati adalah perut membesar (asites). Pada pasien sirosis hati perut semakin membesar karena penimbunan cairan secara abnormal di rongga perut.

Ketika fungsi hati menurun maka lebih banyak garam dan air yang tertahan, cairan juga mungkin berakumulasi dalam rongga perut antara dinding perut dan organ-organ perut. Hal ini menyebabkan pembengkakan perut, ketidaknyamanan perut dan berat badan yang meningkat. Hipertensi portal adalah peningkatan tekanan aliran darah portal lebih dari $15 \mathrm{mmHg}$ yang sifatnya menetap diatas normal, sedangkan tekanan dalam keadaan normal berkisar 5 -10 mmHg. Hasil penelitian menunjukkan 12 pasien mengalami komplikasi sirosis hati dengan hipertensi porta dengan persentase 19,67\% Hipertensi portal paling sering disebabkan oleh sirosis hati (Kusumobroto, 2004).

Berdasarkan penelitian yang sudah dilakukan, penyakit penyerta yang cukup banyak ditemukan pada penderita sirosis hati setelah asites dan hipertensi porta adalah varises esophagus dengan jumlah 7 pasien dengan persentase $11,48 \%$.

Hal ini terjadi karena pada sirosis hati jaringan parut menghalangi aliran darah dan meningkatkan tekanan dalam vena portal (hipertensi portal). Akibat dari aliran darah yang meningkat dan peningkatan tekanan yang diakibatkannya, vena-vena pada kerongkongan yang lebih bawah akan mengembang, yang disebut varises esophagus (Stiphany, dkk, 2011).

Tabel IV. Gambaran peresepan pasien sirosis hati

\begin{tabular}{clcc}
\hline No & Pola Pemberian & Jumlah & $\%$ \\
\hline 1. & Obat Tunggal & 2 & 3,28 \\
2. & Obat Kombinasi (Kombinasi 2 Obat) & 34 & 55,74 \\
& & & \\
3. & Kombinasi Lebih dari 2 Obat & 25 & 40,98 \\
\hline & & 100 \\
\hline
\end{tabular}

Berdasarkan penelitian tentang gambaran peresepan sirosis hati diperoleh hasil 2 pasien mendapatkan terapi pengobatan tunggal dengan persentase 3,28\%, 34 pasien mendapatkan terapi kombinasi 2 obat dengan persentase $55,74 \%$, dan 25 pasien mendapat terapi kombinasi lebih dari 2 obat dengan persentase $40,98 \%$.

Tabel V. Gambaran peresepan sirosis hati menggunakan obat tunggal, kombinasi 2 obat, dan kombinasi lebih dari 2 obat

\begin{tabular}{llccc}
\hline Pola Pemberian & Jenis Obat & Jumlah & $\%$ & \% Total \\
& & & & $\mathbf{3 , 2 8}$ \\
\hline Obat Tunggal & Propranolol & 1 & 1,64 & \\
& Spironolactone & 1 & 1,64 &
\end{tabular}




\begin{tabular}{|c|c|c|c|c|}
\hline Pola Pemberian & Jenis Obat & Jumlah & $\%$ & $\%$ Total \\
\hline \multirow[t]{8}{*}{$\begin{array}{l}\text { Obat kombinasi } \\
\text { (kombinasi } 2 \text { obat) }\end{array}$} & & & & 55,74 \\
\hline & Propranolol + Curcuma & 12 & 19,67 & \\
\hline & Furosemide + Curcuma & 7 & 11,47 & \\
\hline & Spironolactone + Curcuma & 6 & 9,84 & \\
\hline & Furosemide + Albumin & 5 & 8,20 & \\
\hline & Lactulosa + Curcuma & 2 & 3,28 & \\
\hline & Spironolactone + Furosemide & 1 & 1,64 & \\
\hline & Furosemide + Novorapid & 1 & 1,64 & \\
\hline \multirow{9}{*}{$\begin{array}{l}\text { Kombinasi } \\
\text { lebih dari } 2 \text { obat }\end{array}$} & & & & 40,98 \\
\hline & $\begin{array}{l}\text { Propranolol }+ \text { Spironolactone }+ \\
\text { Curcuma }\end{array}$ & 7 & 11,47 & \\
\hline & $\begin{array}{l}\text { Propranolol+Phytomenadione }+ \\
\text { Curcuma }\end{array}$ & 5 & 8,20 & \\
\hline & $\begin{array}{l}\text { Furosemide }+ \text { Novorapid }+ \\
\text { Curcuma }\end{array}$ & 1 & 1,64 & \\
\hline & $\begin{array}{l}\text { Spironolactone }+ \text { Curcuma }+ \\
\text { Inbumin }\end{array}$ & 3 & 4,92 & \\
\hline & Furosemid + Curcuma +Inbumin & 1 & 1,64 & \\
\hline & $\begin{array}{l}\text { Propranolol }+ \text { Spironolactone }+ \\
\text { Phytomenadione }+ \text { Curcuma }\end{array}$ & 4 & 6,55 & \\
\hline & $\begin{array}{l}\text { Propranolol }+ \text { Spironolactone }+ \\
\text { Inbumin }+ \text { Curcuma }\end{array}$ & 2 & 3,28 & \\
\hline & $\begin{array}{l}\text { Propranolol }+ \text { Spironolactone }+ \\
\text { Curcuma }+ \text { Novorapid }\end{array}$ & 2 & 3,28 & \\
\hline Total & & 61 & & 100 \\
\hline
\end{tabular}

Berdasarkan tabel 5, dapat diketahui pemakaian obat tunggal pada penyakit sirosis hati di Instalasi Rawat Jalan Rumah Sakit Panti Waluyo menggunakan propranolol sebanyak 1 pasien dan dari spironolacton sebanyak 1 pasien dengan persentase masing-masing $1,64 \%$

Pemberian Propranolol (golongan Beta Blocker) secara oral dapat menurunkan tekanan portal pada pasien sirosis hati, sebagai akibat penurunan isi semenit jantung dan aliran darah ke dalam hati (liver blood flow), dalam jangka panjang dapat menurunkan resiko perdarahan dan memperbaiki ketahanan hidup pasien pada sirosis hati kompensata yang tanpa asites,baik sebagai profilaktik maupun pengobatan (Kusumobroto, 2004).

Sesuai dengan patofisologisnya, spironolactone dapat memacu natriuresis pada sebagian besar kasus. Pada umumnya diet rendah garam dan spironolactone tetap diperlukan untuk mencegah asites terbentuk lagi. Hanya sedikit pasien yang tetap dapat mempertahankan diuresis dan natriuresis tetapi tanpa pembatasan garam dan bebas dari diuretik (Hirlan,2007).

Berdasarkan hasil penelitian, gambaran peresepan sirosis hati dengan kombinasi dua macam obat yang paling banyak digunakan adalah Propranolol dan Curcuma dengan jumlah pasien 12 dengan persentase 19,67\% dari semua sampel pasien sirosis hati.

Propranolol banyak digunakan pada pasien sirosis hati dengan komplikasi hipertensi porta. Menurut penelitian Purnomo, dkk (2012) tekanan dinding varises merupakan faktor utama yang menentukan rupturnya varises. Berdasarkan resiko perdarahan varises pada pasien sirosis hati dengan hipertensi porta yang dapat menyebabkan kematian maka penggunaan propranolol diharapkan dapat menekan angka kejadian perdarahan varises.

Berdasarkan hasil penelitian, curcuma banyak digunakan pada terapi pengobatan. 
Curcuma digunakan di dalam terapi pengobatan pasien gangguan hati, berfungsi sebagai hepatoprotektif karena sebagai antiradang sekaligus antioksidan. Hepatoprotektif digunakan untuk melindungi hati sehingga dapat memperlambat kerusakan sel hati dan mencegah kerusakan hati lebih lanjut (Virgonita.,dkk, 2012).

Pada pasien asites, selain digunakan golongan diuretik untuk mengatasi edema yang muncul, penggunaan hepatoprotektif sudah tepat. Hal ini dikarenakan penggunaan curcuma yang berperan sebagai hepatoprotektif diharapkan dapat melindungi hati dan mencegah kerusakan sel hati lebih lanjut (Virgonita.,dkk, 2012).

Menurut penelitian Setiawan (2011), salah satu manifestasi dari sirosis hati adalah menurunnya kadar albumin. Sintesis albumin hanya terjadi di hepar, akan tetapi laju produksi ini bervariasi tergantung keadaan penyakit dan laju nutrisi karena albumin hanya dibentuk pada lingkungan osmotic, hormonal dan nutrisi yang cocok. Berdasarkan hasil penelitian albumin digunakan bersama kombinasi furosemide dengan jumlah pasien 5 dengan presentase $8,20 \%$, sudah tepat. Hal ini dikarenakan penambahan albumin diharapkan dapat menekan resiko terjadinya Spontaneus Bacterial Peritonitis pada penderita sirosis hati dengan asites, dan untuk mengatasi munculnya hipoalbumin pada pasien sirosis hati yang ditandai dengan turunnya kadar albumin berdasar hasil pemeriksaan laboratorium.

Lactulosa digunakan bersama kombinasi curcuma untuk pasien sirosis hati komplikasi ensefalopati hati. Ensefalopati hati merupakan kelainan neuropsikiatrik akibat disfungsi hati. Mula-mula ada gangguan tidur (insomnia dan hipersomnia), selanjutnya dapat timbul gangguan kesadaran yang berlanjut sampai koma. Lactulosa dapat menghambat produksi dan penyerapan ammonia di dalam usus, dan meningkatkan eliminasi ammonia melalui feses (Nurdjanah, 2007).

Pasien sirosis hati yang menderita diabetes melitus sebagai penyakit penyerta dan memperoleh terapi novorapid kombinasi dengan furosemide dengan jumlah 1 pasien dengan persentase $1,64 \%$. Penyakit sirosis hati yang disertai dengan diabetes melitus dapat menyebabkan terjadinya perubahan farmakokinetik dan farmakodinamik obat dalam tubuh, sehingga pengobatan penderita 6 penyakit sirosis hati dengan diabetes mellitus menjadi sangat kompleks karena adanya kerusakan hati dan hepatotoksisitas obat hipoglikemik oral.

Pada pasien sirosis hati yang disertai dengan diabetes melitus, penggunaan novorapid (insulin rapid acting) sudah tepat. $\mathrm{Hal}$ ini dikarenakan insulin sering digunakan pada pasien penyakit hati dengan diabetes melitus karena dianggap merupakan antihiperglikemik paling aman dan efektif dengan memperhatikan penyesuaian dosis dan resiko hipoglikemia pada pasien (Lorensia.,dkk, 2016). Berdasarkan hasil penelitian didapatkan beberapa terapi pengobatan yang menggunakan kombinasi bersama phytomenadion tablet. Phytomenadion tablet digunakan didalam terapi sirosis hati untuk mengatasi munculnya melena dan hematoemesis yang diakibatkan oleh komplikasi varises esofagus. Phytomenadion dapat digunakan dalam membantu proses pembekuan darah, dan dapat mencegah pendarahan pada hati.

Penggunaan vitamin $\mathrm{K}$ biasanya banyak digunakan pada pasien dengan diagnosa varises esofagus yang sudah disertai melena dan hematemesis maupun untuk terapi pencegahan munculnya kedua akibat dari varises esofagus tersebut.

\section{SIMPULAN}

1. Karakteristik pasien sirosis hati di Instalasi Rawat Jalan Rumah Sakit Panti Waluyo pada tahun 2019 paling banyak pada pasien dengan jenis kelamin laki-laki dengan persentase $55,74 \%$, usia pasien yang paling banyak adalah usia 18-65 tahun dengan persentase $90,16 \%$. Berdasarkan diagnosis pasien (dengan atau tanpa penyakit penyerta) lebih didominasi oleh pasien sirosis hati dengan asites sebanyak $39,34 \%$.

2. Gambaran peresepan sirosis hati di Instalasi Rawat Jalan Rumah Sakit Panti Waluyo pada tahun 2019 dengan obat tunggal sebanyak 2 pasien yaitu golongan $\beta$-Blocker (propranolol) dan golongan Diuretik Hemat Kalium(spironolactone), masing-masing sebanyak 1 pasien (1,64\%). Penggunaan obat sirosis hati dengan dua macam kombinasi sebanyak 12 pasien dengan persentase 19,67\% menggunakan kombinasi propranolol dan curcumin. 
3. Kombinasi lebih dari dua macam obat sirosis hati sebanyak 7 pasien dengan persentase $11,47 \% \quad$ menggunakan kombinasi propranolol + spironolactone + curcuma.

\section{UCAPAN TERIMA KASIH}

Ucapan terrima kasih dan penghargaan diberikan kepada editor yang telah menelaah dan mereview Journal Of Pharmacy, dan kepada semua pihak yang telah membantu penulis untuk menyelesaikan penulisan Karya Tulis Ilmiah Ini.

\section{DAFTAR PUSTAKA}

Farida, Yeni, Tri Murti Andayani, dan Neneng Ratnasari, 2014, "Analisis Penggunaan Obat pada Komplikasi Sirosis Hati", Jurnal Manajemen dan Pelayanan Farmasi, Volume 4(2): 77-84, UGM, Yogyakarta.

Hirlan, "Sirosis Hati". In : Sudoyo, Aru W., et al., ed. 2007, Buku Ajar Ilmu Penyakit Dalam. Jakarta: Pusat Penerbitan Departemen Ilmu Penyakit Dalam Fakultas Kedokteran Universitas Indonesia.

Kusumobroto, H. "Sirosis Hati". In : Noer, Sjaifoellah., et al., ed.2004 , Buku Ajar Ilmu Penyakit Dalam. Jakarta: Pusat Penerbitan Departemen Ilmu Penyakit Dalam Fakultas Kedokteran Universitas Indonesia.

Lorensia, Amelia, Ernie Gorisalam, 2016, "Analisis Masalah Terkait Obat Pengobatan Antidiabetes pada Pasien Sirosis Hati Dengan Diabetes Mellitus Tipe 2 Di Suatu Rumah Sakit Di Surabaya", Jurnal Ilmiah Sains Dan Teknologi, Vol. 9(2): 58-73, Departemen Farmasi Klinis-Komunitas, Fakultas Farmasi, Universitas Surabaya.

Lovena, Angela, Saptino Miro, dan Efrida, 2017, "Karakteristik Pasien Sirosis Hepatis di RSUP Dr. M. Djamil Padang", Jurnal Kesehatan Andalas, Volume 6(1): 6-12, Universitas Andalas, Padang.

Notoatmodjo, S, $\quad$ 2012,Metodologi Penelitian Kesehatan PT.Rineka Cipta,Jakarta
Nurdjanah, S. "Sirosis Hati". In : Sudoyo, Aru W., et al., ed. 2007, Buku Ajar Ilmu Penyakit Dalam. Jakarta: Pusat Penerbitan Departemen Ilmu Penyakit Dalam Fakultas Kedokteran Universitas Indonesia.

Patasik, Yunellia Z., Bradley J. Waleleng, dan Frans Wantania, 2015, "Profil Pasien Sirosis Hati yang Dirawat Inap di RSUP Prof. Dr. R. D. Kandou Manado Periode Agustus 2012-2014", Jurnal e-Clinic (eCl) Volume 3 (1): 342-347, Univeritas Sam Ratulangi, Manado.

Purnomo, Eka, Djoko Wahyono, dan Dewa Putu Pramantara 2012, “Akibat Penggunaan Obat Antihipertensi Portal terhadap Episode Kejadian HematemesisMelena Pada Pasien Sirosis Hati Di RSUP Dr. Sardjito Yogyakarta", Majalah Farmasuetik, Volume 8(3): 208-213, Farmasi UGM, Yogyakarta.

Setiawan, Meddy, 2011, "Hubungan Antara Kejadian Asites Pada Cirrbosis Hepatis Dengan Komplikasi Spontaneous Bacterial Peritonitis", Vol. 7(15): 79-93, Bagian Ilmu Penyakit Dalam , Fakultas Kedokteran, Universitas Muhammadiyah Malang.

Stiphany, Hiswadi, Jemadi, 2011, "Karakteristik Penderita Sirosis Hati Rawat Inap di RSUD DR Pirngadi Medan Tabun 20101-2011", Universitas Sumatera Utara.

Sukandar, Yulinah E., et al., 2009, "Iso Farmakoterapi”. Jakarta : PT. ISFI Penerbitan.

Tarigan, P. "Sirosis Hati". In : Noer, Sjaifoellah., et al., ed.2004 , Buku Ajar Ilmu Penyakit Dalam. Jakarta: Pusat Penerbitan Departemen Ilmu Penyakit Dalam Fakultas Kedokteran Universitas Indonesia.

Virgonita, Septina, A Karim Zulkarnain, 2012, "Pola Penggunaan Obat pada Pasien Sirosis Hati di Instalasi Rawat Inap Bangsal Penyakit Dalam Rumah Sakit Dr.Sardjito Yogyakarta", Majalah Farmasuetik, Volume 8(3): 218-226, Farmasi UGM, Yogyakarta. 